\title{
INFLUENCE OF ENTREPRENEURS ON JOB SATISFACTION AND ORGANIZATIONAL COMMITMENT OF EMPLOYEES
}

\author{
UDC: 005.511:331.101.3 \\ Original Scientific Paper
Jesa KREINER ${ }^{1}$, Dragana SAJFERT ${ }^{2}$, Svetlana ANĐELIĆ ${ }^{2}$, Nikola JANČEV ${ }^{3}$, Milorad ŽIVKOVIĆ ${ }^{4}$ \\ ${ }^{1}$ California State University, Fullerton, Los Angeles, California, USA \\ 2ITS Information Technology School, 11080 Belgrade-Zemun, 34, Cara Dušana, Republic of Serbia \\ E-mail: sdragana77@ hotmail.com \\ 2ITS Information Technology School, 11080 Belgrade-Zemun, 34, Cara Dušana, Republic of Serbia \\ ${ }^{3}$ Novi Sad School of Business, 21000 Novi Sad, 4, Vladimira Perića - Valtera, Republic of Serbia \\ ${ }^{4}$ International University, Brčko, bb, M.Malića \& I.Džindića, Brčko District, Bosnia and Herzegovina
}

Paper received: 29.08.2021.; Paper accepted: 29.09.2021.

\begin{abstract}
In this paper, we analyze reliability, correlations, regression of employee obligations, compare employee regression, job satisfaction regression, and hierarchical regression analysis. As techniques for comparison of entrepreneurs and employees are significant for analysis of positive correlations between the determinants, we used 36 independent samples and 210 individuals. The findings reveal that: (1) The results of the research confirmed the existence of a statistically significant positive correlation between the determinants of job satisfaction and organizational commitment on one hand, and the work of entrepreneurs, on the other; (2) The results of the survey compare the relationship between entrepreneurs and employee job satisfaction and organizational commitment, adding a significant increase in the importance of the construct; (3) Entrepreneurship has a relative correlation in relation to job satisfaction, and organizational commitment, and thus increases the scope of tasks and efficiency of entrepreneurs; (4) Entrepreneurs show dominance over employee satisfaction and organizational commitment, when they predict the success of a group or organization and organizational civic behavior. We recommend that future researches examine the relationship among entrepreneurs and their relationship with employees, as well as job satisfaction and organizational commitment, in order to potentially compare them.
\end{abstract}

Keywords: Entrepreneurship; Job satisfaction; Organizational commitment; Efficiency of entrepreneurs.

\section{INTRODUCTION}

The hypothesis that entrepreneurship is linked to economic growth finds its most immediate foundation in simple intuition, common sense and pure economic observation: activities to convert ideas into economic opportunities lie at the very heart of entrepreneurship. Entrepreneurship is a source of innovation and change, and as such spurs improvements in productivity and economic competitiveness (United Nations Conference, 2005).

This paper presents a summary of contemporary thoughts on which skills are necessary to succeed in the fiercely competitive workplace going above and beyond the normal professional skills required in the field, the influence of entrepreneurs on job satisfaction and organizational commitment of employees (Kreiner, 2011). In this author's opinion, the ability to understand the culture of the workplace are among the most important ones (Kreiner, 2011). An entrepreneur should have the ability to lucidly and consistently express and present ideas, the ability to cope with the ups and downs of the economy (Kreiner, 2011). An entrepreneur should have social responsibility and have creativity in solving problems. The entrepreneur must have a basic line of willingness to take risks, and also have an understanding of the political realities in the institution, and a demonstrated willingness to improve knowledge in the field, thus avoiding product obsolescence (Kreiner, 2011). 
Entrepreneurship is closely associated with knowledge and flexibility, two factors that have gained new significance as a source of competitiveness in an increasingly globalized world economy. With technological changes and intensified global competition brought about by globalization and economic liberalization, the assumption that fostering entrepreneurship means fostering a country's competitiveness today appears more valid than ever (United Nations Conference, 2005).

In the current global corporate climate that surrounds us, firms would do well to encourage the talent and creativity of their employees to achieve success. This is achieved, not by giving priority to individual talent, but by optimizing the collective as a whole and with the firm's activities based on teamwork and joint effort (Akehurst, Comeche, \& Galindo, 2009).

The process used to identify the themes that characterize entrepreneurship took the form of a policy Delphi. This Delphi was constructed as a series of three questionnaires to elicit definitions of entrepreneurship that were then analyzed and evaluated (Gatner, 1990). The entrepreneur theme is the idea that entrepreneurship involves individuals with unique personality characteristics and abilities (Gatner, 1990).

Sajfert et al. (2017b) noted that their paper presents the results of the study of the influence of the leader's ethical behavior on individual and organizational performance in enterprises in Serbia. Specifically, the study consists of examination of (EL) influence on job satisfaction (JS), organizational commitment (OCM).

This study aims at introduction of subjective risk intelligence (SRI) in the context of small businesses to analyze how both rationality and intuition may influence the entrepreneurial decision-making process, particularly in affecting firms' financial equilibrium (Puglisi et al., 2021). The rational component seems to stimulate the entrepreneurial orientation to risk tolerance. Results show that the intuitive and the rational components of risk intelligence affect entrepreneurs' decision-making differently. The intuitive component limits the entrepreneurial propensity to take financial risks due to desire for stability attached to this cognitive process (Puglisi et al., 2021).
Practical implications suggest that entrepreneurs with a dominant attitude towards problem-solving self-efficacy, or a positive attitude towards uncertainty, should invest in developing imaginative capabilities or emotional control, and vice versa (Puglisi et al., 2021).

Although the literature on affect (i.e. the extent to which an individual subjectively experiences feelings and emotions) is burgeoning in the field of entrepreneurship, affect has not received sufficient attention with respect to an important antecedent to entrepreneurial success - entrepreneurial orientation (Bernoster, Mukerjee, \& Thurik, 2020).

We examine the implications for growth and development of existence of two types of human capital: entrepreneurial and professional. Entrepreneurs accumulate human capital through a work-experience intensive process, whereas professionals' human capital accumulation is education-intensive (Iyigun \& Owen, 1999).

The contributions and shortcomings of past entrepreneurship researches can be viewed within the context of six research design specifications: purpose, theoretical perspective, focus, level of analysis, time frame and methodology (Low \& McMillan, 1988).

This article develops a framework to demonstrate how employee job satisfaction influences entrepreneurial intentions. Based on a new institutional theory, we examine our hypotheses using data from 39,394 employees from 27 countries; the results indicate that job satisfaction has a negative effect on entrepreneurial intentions moderated by uncertainty avoidance at the country level (Li et al., 2021).

Dragana Sajfert and associates (Sajfert et al., 2017a) conducted a study on the behavior of the big five personality factors for general job satisfaction. The results of the meta-analysis between the big five traits and job satisfaction are:

- for neuroticism the correlation score is -.28 , and for standard deviation .15,

- for openness the correlation score is .24 , and for standard deviation .14,

- for openness to experience the correlation score is .021, and for standard deviation .20,

- for compliance, the correlation score is .16, and for standard deviation .15 
- for conscientiousness the correlation score is .25 , and for standard deviation .21.

While developing growth of economies as standard, economic growth models predict that (through the accumulation of human and physical capital and increasing specialization) once an economy has entered the industrialized phase of capitalist development, a qualitative change in the drivers of economic growth occurs (Peretto, 1999). The founders of business are accountable for availability of goods and services and for creation of new opportunities (Chandler \& Hanks, 1994).

McClelland also suggests that, regardless of variations in economic development, entrepreneurs with high motivation will almost always find ways to maximize economic achievement. He identifies 10 personal entrepreneurial competencies for detecting and strengthening entrepreneurial potential, which are remarkably consistent from country to country: (1) opportunity seeking and initiative; (2) risk taking; (3) demand for efficiency and quality; (4) persistence; (5) commitment to the work contract; (6) information seeking; (7) goal setting; (8) systematic planning and monitoring; (9) persuasion and networking; and (10) independence and self-confidence (McClelland, 1961).

Entrepreneurs are a rare species. Even in innovation-driven economies, only $1-2 \%$ of the work force starts a business in any given year. Yet entrepreneurs, particularly innovative entrepreneurs, are vital to the competitiveness of the economy. The gains of entrepreneurship are only realized, however, if the business environment is receptive to innovation. In addition, policymakers need to prepare for the potential job losses that can occur in the medium term through "creative destruction" as entrepreneurs strive for increased productivity (Kritikos, 2015).

The main purpose of this paper is to examine the character of relationship between the application of job satisfaction and organizational commitment and the intensity of intentions to start your own entrepreneurial venture. Job satisfaction is one of the most researched topics in the field of human behavior in organizations, which is the reason why the authors explore a segment of influence of entrepreneurs on job satisfaction and organizational commitment of employees. The reason why job satisfaction is one of the most researched topics is the belief that a satisfied worker is a productive worker. So, if an entrepreneur wants his company to be successful, he cannot achieve that with dissatisfied employees. Therefore, Spector (1997) sees the term job satisfaction as the most commonly used variable in organizational behavior. According to Martin and Miller (1986) job dissatisfaction may be the main factor for reduction of production.

The results of Hertzberg's research (1987) also emphasized that the potential power of motivation factor as a factor, job satisfaction depends on the personality. Hertzberg (1987) calls such people ,people who are looking for a motive to work“. On the other hand, Hertzberg (1987) argues that „people looking for good conditions“ are most motivated by their working conditions and tend to avoid other motives for work. Organizational commitment of employees could be treated as a certain extension of job satisfaction. According to Greenberg and Baron (1995), organizational commitment of employees represents the positive attitudes that the employee does not feel towards his job, as is the case when he is satisfied with the job, but towards the organization as a whole. The organizational commitment component of employees is related to the feelings of employees to fulfill their obligations to connect with the organization. Kanter (1968) states that cohesion commitment refers to the attachment of individuals to affectivity and emotion with a group.

Appropriate sampling techniques and method have been developed, and have yielded results that we will present below. A new future research is necessary in order to confirm the results obtained by this research, or to obtain completely different results. The entrepreneur should conduct a survey near employees in the company (how satisfied they are with the job). If the entrepreneur gives us enough time to conduct an employee survey, he should hire a consulting group. In this way, the entrepreneur would have the "temperature" within the company in the palm of his hand, so they provide them with insights into areas that can be improved.

\section{LITERATURE REVIEW}

A group of authors Ćoćkalo et al. (2017) conducted a very interesting research in which she analyzed the improvement of entrepreneurial behavior of younger people. The research was conducted in the Central Banat District, and the results of attitudes of young people towards 
entrepreneurship and starting their own business were obtained.

According to the research by Ćoćkalo et al. (2017), it may be concluded that young people are often unmotivated to start their own business. Ćoćkalo et al. (2017) state in the research that young people are most often hindered by: lack of resources, lack of experience in running companies, lack of knowledge and original ideas. Elements that affect the fact that you do not start your own business is the lack of appropriate environment that would help young people in starting a business. Unemployment is seen as a problem of young people by Djordjević and Ćoćkalo (2017) and they state that it is one of the key economic problems. They believe that all relevant institutions must be involved in solving these problems. In order to stimulate and involve young people in entrepreneurship, they should be referred to entrepreneurial incubators. There they could realize their creativity and ideas.

Richard Cantillon was the first to use the word entrepreneur in his essay on the nature of trade, which he wrote around 1730. Josef Schumpeter (1935) is certainly one of the most important figures in the history of entrepreneurship. The topic of this research is related to the educational literature of Henderson and Hoy (1983). Avolio et al. (2004), and Jensen and Luthans (2006) are the bearers of this type of entrepreneurship research. Further concepts of entrepreneurship research are motivated by employees in global competition (Hamel, 2000; O'Reilly, \& Pfeffer, 2000). Research determinates that competitive advantage in a company comes from the human side of entrepreneurship (Argyris, 1993; Hitt, \& Duane, 2002; Pfeffer, 1998). Business ethics in entrepreneurship makes this concept very interesting for future research.

Harter et al. (2003) investigated 7,939 business units in 36 organizations, this study uses metaanalysis and examined the relationship at the level of business units between employees and job satisfaction and business satisfaction results, their productivity, profit, turnover and employee satisfaction.

Several different personality variables have been linked to job satisfaction. Locke (1976) cites selfesteem. Scheier and co-workers (1986) report the ability to cope with stress. The research has shown that people who own more of these sizes will be more satisfied with their job.

Dajani and Zaki (2015) conducted a research study that aims to identify the key engagement of employees in entrepreneurial companies in Egypt. In their study Dajani and Zaki (2015) studied the impact of employee engagement on job performance and organizational commitment based on social exchange theory (SET). In the study, they used regression analysis that helped them discover and explain the proposed relationship. The study was conducted at several private and public banks operating in Cairo-Egypt. The results of the regression showed that entrepreneurs pay attention to organizational justice and that it is the most important driver of greater employee engagement. The effect of this engagement has been confirmed. In their research Dajani and Zaki (2015) confirmed that increased employee engagement has a significant impact on job performance, but less impact on organizational commitment.

Robbins (2002) states the differences between management and entrepreneurship, he also deals with the founders of companies - entrepreneurs. Hiam (2002a) in his paper talks about the trust of employees in growing business entrepreneurship. According to Hiam (2002b), little attention began to be paid to entrepreneurs and small business owners as leaders. Hiam (2002b) points to great abilities of business founders as well as to conveying a vision to their employees. A number of studies demonstrated impact of founder in the supply of financial and human capital (Gimeno et al., 1997).

Much of attention has been given to founder/ entrepreneur in the strategy entrepreneurship literature and job satisfaction and little attention is diverted towards industrialist as an entrepreneur who affects the attitude of work and rhetoric's of employees of him or her.

\section{METHODOLOGY}

\section{Hypothesis}

$H 1$ - There is a positive significant relationship among entrepreneurs and employee commitment.

$H 2$ - There is a positive significant relationship among entrepreneurs and job satisfaction. 


\section{Sample}

The survey is self-administrated and paper-andpencil method was used. A total of 240 questionnaires were distributed among employees in small enterprises and entrepreneurs. 80 questionnaires were distributed in the USA, Serbia and Bosnia and Herzegovina. Out of these questionnaires, 10 were rejected in each group, due to indecent and incomplete answers. Approximately $40 \%$ is filled in the public sector, $60 \%$ in the private sector. About $60 \%$ of respondents are up to 45 years old, about $40 \%$ are over 45 years old.

\section{Instruments}

The multifactor entrepreneurs' questionnaire gives an explanation about style of entrepreneurs. Responses are obtained on 5-point Likert scales (Likert, 1932).

The OCS made by the Balfour and Barton (1996) to estimate the dimension of org. commitment using 7-point Likert scales (Likert, 1932). The job satisfaction is measured using 7-point Likert scales. The reliability of entrepreneurs is .756 , organizational commitment is .475 and job satisfaction is .536. in USA. The reliability of entrepreneurs is .709 , organizational commitment is .531 and job satisfaction is .624. in Serbia. The reliability of entrepreneurs is .725 , organizational commitment is .589 and job satisfaction is .579. in Bosnia and Herzegovina.

\section{RESULTS}

\section{Reliability}

The reliability value of entrepreneurs (Table 1.), employee commitment and job satisfaction are measured by Cronbach's Alpha. According to the results, the Alpha coefficient of entrepreneurs is 0.756 , Employee commitment is 0.475 and the Job Satisfaction is 0.536 in USA. The Alpha coefficient of entrepreneurs is 0.709, Employee commitment is 0.531 and the Job Satisfaction is 0.6246 in Serbia. The Alpha coefficient of entrepreneurs is 0.725 , Employee commitment is 0.589 and the Job Satisfaction is 0.579 in Bosnia and Herzegovina.
Table 1: Reliability analyses

US Sample 1

\begin{tabular}{|l|c|c|c|}
\hline Variables & Entrepreneurs & $\begin{array}{c}\text { Employee } \\
\text { Commitment }\end{array}$ & $\begin{array}{c}\text { Job } \\
\text { Satisfaction }\end{array}$ \\
\hline Alfa Value & 0.756 & 0.475 & 0.536 \\
\hline
\end{tabular}

Serbia Sample 1

\begin{tabular}{|l|c|c|c|}
\hline Variables & Entrepreneurs & $\begin{array}{c}\text { Employee } \\
\text { Commitment }\end{array}$ & $\begin{array}{c}\text { Job } \\
\text { Satisfaction }\end{array}$ \\
\hline Alfa Value & 0.709 & 0.531 & 0.624 \\
\hline
\end{tabular}

Bosnia and Herzegovina Sample 1

\begin{tabular}{|l|c|c|c|}
\hline Variables & Entrepreneurs & $\begin{array}{c}\text { Employee } \\
\text { Commitment }\end{array}$ & $\begin{array}{c}\text { Job } \\
\text { Satisfaction }\end{array}$ \\
\hline Alfa Value & 0.725 & 0.589 & 0.579 \\
\hline
\end{tabular}

\section{Correlations}

The results in Table 2. show that there is a positive connection in entrepreneurship and employee commitment $(\mathrm{r}=.483, \mathrm{p}<0.01)$ and also a positive relationship in entrepreneurs and job satisfaction and $(\mathrm{r}=.124, \mathrm{p}<0.01)$ so $\mathrm{H} 1$ and $\mathrm{H} 2$ are acceptable.

\section{Table 2: Correlations}

US Sample 2

\begin{tabular}{|l|l|c|c|c|}
\hline & & EN & EC & JS \\
\hline \multirow{3}{*}{ Entrepreneurs } & Correlation coeff. & 1.00 & $.453(* *)$ & $.132(*)$ \\
& Sig. (1-tailed) & .000 & .000 & .039 \\
& $\mathrm{~N}$ & 70 & 70 & 70 \\
\hline \multirow{2}{*}{ Employee } & Correlation coeff. & $.472(* *)$ & 1.100 & $.201(* *)$ \\
Commitment & Sig. (1-tailed) & .000 & .000 & .001 \\
& $\mathrm{~N}$ & 70 & 70 & 70 \\
\hline \multirow{3}{*}{ Job Satisfaction } & Correlation coeff. & $.119\left(^{*}\right)$ & $.212\left(^{*}\right)$ & 1.980 \\
& Sig. (1-tailed) & .032 & .002 & .000 \\
& $\mathrm{~N}$ & 70 & 70 & 70 \\
\hline \multicolumn{4}{|c|}{ ** Correlation is significant at 0.01 level (1-tailed). } \\
* Correlation is significant at 0.05 level (1-tailed).
\end{tabular}

Serbia Sample 2

\begin{tabular}{|l|l|c|c|c|}
\hline \multicolumn{2}{|c|}{ Serbia Sample 2} \\
\hline \multirow{3}{*}{ Entrepreneurs } & EN & EC & JS \\
& Correlation coeff. & 1.10 & $.474(* *)$ & $.120(*)$ \\
& Sig. (1-tailed) & .000 & .000 & .036 \\
& $\mathrm{~N}$ & 70 & 70 & 70 \\
\hline \multirow{2}{*}{ Employee } & Correlation coeff. & $.497(* *)$ & .160 & $.251(* *)$ \\
Commitment & Sig. (1-tailed) & .000 &. & .002 \\
& $\mathrm{~N}$ & 70 & 70 & 70 \\
\hline \multirow{3}{*}{ Job Satisfaction } & Correlation coeff. & $.117(*)$ & $.243(* *)$ & 1.750 \\
& Sig. (1-tailed) & .032 & .002 & .000 \\
& $\mathrm{~N}$ & 70 & 70 & 70 \\
\hline
\end{tabular}

** Correlation is significant at 0.01 level (1-tailed).

* Correlation is significant at 0.05 level (1-tailed).

Bosnia and Herzegovina Sample 2

\begin{tabular}{|l|l|c|c|c|}
\hline & & EN & EC & JS \\
\hline \multirow{3}{*}{ Entrepreneurs } & Correlation coeff. & 1.11 & $.482(* *)$ & $.231(*)$ \\
& Sig. (1-tailed) & .000 & .000 & .036 \\
& $\mathrm{~N}$ & 70 & 70 & 70 \\
\hline \multirow{2}{*}{ Employee } & Correlation coeff. & $.442(* *)$ & 1.220 & $.242(* *)$ \\
Commitment & Sig. (1-tailed) & .000 & .000 & .0012 \\
& $\mathrm{~N}$ & 70 & 70 & 70 \\
\hline \multirow{3}{*}{ Job Satisfaction } & Correlation coeff. & $.121\left(^{*}\right)$ & $.241(* *)$ & 1.6030 \\
& Sig. (1-tailed) & .034 & .003 & .003 \\
& $\mathrm{~N}$ & 70 & 710 & 70 \\
\hline \multicolumn{4}{|c|}{ ** Correlation is significant at 0.01 level (1-tailed). } \\
* Correlation is significant at 0.05 level (1-tailed).
\end{tabular}




\section{Linear Regression}

In Table 3. $\mathrm{R}^{2}$ shows variance in employee commitment due to entrepreneurship and that is ( $\mathrm{R} 2=0.252)$, which is significant. Value of $\mathrm{F}$ is 70.134 that is significant and level of significance is $(p<0.01)$, which is totally acceptable and which tells that independent variable create variance in dependent variable. Value of standardized Beta of entrepreneurship is 8.375 , which is significant having value i.e. $(\mathrm{p}<0.01)$ and which shows a significant impact of entrepreneurship on employee commitment.

\section{Table 3: Regression of Employee Commitment} US Sample 3

\begin{tabular}{|l|c|c|c|c|c|}
\hline \multicolumn{1}{|c|}{ Variable } & $\alpha$ & $\begin{array}{c}\text { Std. } \\
\text { error }\end{array}$ & $\begin{array}{c}\text { Standardized } \\
\text { coefficient }\end{array}$ & t-value & Sig \\
\hline Constant & 2.275 & .343 & - & 16.537 & .000 \\
\hline Entrepreneurs & 1.072 & .127 & .128 & 1.876 & .043 \\
\hline $\mathrm{R}^{2}$ & .248 & - & 4.621 & - & - \\
\hline \multicolumn{7}{|c|}{ Dependent Variable = Employee Commitment }
\end{tabular}

Serbia Sample 3

\begin{tabular}{|l|c|c|c|c|c|}
\hline \multicolumn{1}{|c|}{ Variable } & $\alpha$ & $\begin{array}{c}\text { Std. } \\
\text { error }\end{array}$ & $\begin{array}{c}\text { Standardized } \\
\text { coefficient }\end{array}$ & t-value & Sig \\
\hline Constant & 2.275 & .343 & - & 16.537 & .000 \\
\hline Entrepreneurs & 1.072 & .127 & .128 & 1.876 & .043 \\
\hline $\mathrm{R}^{2}$ & .248 & - & 4.621 & - & - \\
\hline \multicolumn{7}{|c}{ Dependent Variable= Employee Commitment }
\end{tabular}

Bosnia and Herzegovina Sample 3

\begin{tabular}{|l|c|c|c|c|c|}
\hline \multicolumn{1}{|c|}{ Variable } & $\alpha$ & $\begin{array}{c}\text { Std. } \\
\text { error }\end{array}$ & $\begin{array}{c}\text { Standardized } \\
\text { coefficient }\end{array}$ & t-value & Sig \\
\hline Constant & 2.275 & .343 & - & 16.537 & .000 \\
\hline Entrepreneurs & 1.072 & .127 & .128 & 1.876 & .043 \\
\hline $\mathrm{R}^{2}$ & .248 & - & 4.621 & - & - \\
\hline
\end{tabular}

Dependent Variable= Employee Commitment

In Table 4. $\mathrm{R}^{2}$ shows variance in job satisfaction due to authentic entrepreneurship and that is .017 , which is significant. Value of $F$ is 4.632 , which is significant and level of significance having value i.e. $(p<.01)$, which is totally acceptable and which tells that independent variable create variance in dependent variable. Value of standardized Beta of Entrepreneurs is $(\beta=0.131)$, which is significant. This shows a significant impact of entrepreneurship on employee commitment.

Hierarchical regression analysis was used to examine the moderator effect of half of the respondents. Hierarchical regression analysis examined the significance of regression coefficient with the product of predictor variable for the independent variables EL and the dependent variables EC and JS and the moderator variables of sex of the respondents. The results of hierarchical regression analysis ( $\mathrm{R}$ square and F-change) are presented in Table 5, and only the results in which the moderating effect of half of the respondents was confirmed.

Table 4: Regression of Job Satisfaction US Sample 4

\begin{tabular}{|l|c|c|c|c|c|}
\hline \multicolumn{1}{|c|}{ Variable } & $\alpha$ & Std. error & $\begin{array}{c}\text { Standardized } \\
\text { coefficient }\end{array}$ & t-value & Sig \\
\hline Constant & 5.389 & .321 & - & 16.592 & .000 \\
\hline Entrepreneurs & .215 & .113 & .127 & 1.901 & .041 \\
\hline $\mathrm{R}^{2}$ & .16 & F-Statistic & 4.621 & - & - \\
\hline \multicolumn{5}{|c}{ Dependent Variable=Job Satisfaction }
\end{tabular}

Serbia Sample 4

\begin{tabular}{|c|c|c|c|c|c|}
\hline Variable & $\alpha$ & Std. error & $\begin{array}{c}\text { Standardized } \\
\text { coefficient }\end{array}$ & t-value & Sig \\
\hline Constant & 5.389 & .321 & - & 16.592 & .000 \\
\hline Entrepreneurs & .215 & .113 & .127 & 1.901 & .041 \\
\hline $\mathrm{R}^{2}$ & .16 & F-Statistic & 4.621 & - & - \\
\hline \multicolumn{6}{|c|}{ Dependent Variable $=$ Job Satisfaction } \\
\hline \multicolumn{6}{|c|}{ Bosnia and Herzegovina Sample 4} \\
\hline Variable & $\alpha$ & Std. error & $\begin{array}{c}\text { Standardized } \\
\text { coefficient }\end{array}$ & t-value & Sig \\
\hline Constant & 5.389 & .321 & - & 16.592 & .000 \\
\hline Entrepreneurs & .215 & .113 & .127 & 1.901 & .041 \\
\hline $\mathrm{R}^{2}$ & .16 & F-Statistic & 4.621 & - & - \\
\hline
\end{tabular}

Table 5: Hierarchical regression analysis $(R$ square and $F$-change) for gender of respondents as moderator (only pairs in which the moderation effect of gender of respondents was commitment) US Sample 5

\begin{tabular}{|c|c|c|c|}
\hline Independent & Dependent & R square & F-change \\
\hline EN & CS4 & .357 & 3.676 \\
\hline EC & OL6 & .261 & 4.759 \\
\hline JS & OL7 & .271 & 3.346 \\
\hline
\end{tabular}

Serbia Sample 5

\begin{tabular}{|c|c|c|c|}
\hline Independent & Dependent & R square & F-change \\
\hline EN & CS3 & .363 & 3.876 \\
\hline EC & OL3 & .411 & 3.234 \\
\hline JS & OL6 & .119 & 4.759 \\
\hline
\end{tabular}

Bosnia and Herzegovina Sample 5

\begin{tabular}{|c|c|c|c|}
\hline Independent & Dependent & R square & F-change \\
\hline EN & CS5 & .417 & 3.646 \\
\hline EC & OL4 & .345 & 3.719 \\
\hline JS & OL5 & .323 & 3.214 \\
\hline
\end{tabular}

Hierarchical regression analysis was used to examine the moderator effect of age of the respondents. Hierarchical regression analysis examined the significance of regression coefficient with the product of the predictor variable for the independent variables EL and the dependent variables EC and JS and the moderator of age of 
the respondents. The results of the hierarchical regression analysis ( $\mathrm{R}$ square and F-change) are presented in Table 6, and only the results in which the moderating effect of age of the respondents was confirmed.

Table 6: Hierarchical regression analysis ( $R$ square and $F$-change) for age of the respondents as moderator (only pairs in which the moderation effect of age of the respondents was confirmed)

\begin{tabular}{|c|c|c|c|c|c|c|c|c|c|c|c|}
\hline \multicolumn{4}{|c|}{ US Sample 6} & \multicolumn{4}{|c|}{ Serbia Sample 6} & \multicolumn{4}{|c|}{ Bosnia and Herzegovina Sample 6} \\
\hline Indep. & Dep. & $\begin{array}{c}\mathrm{R} \\
\text { square }\end{array}$ & $\begin{array}{c}\text { F- } \\
\text { change }\end{array}$ & Indep. & Dep. & $\begin{array}{c}\mathrm{R} \\
\text { square }\end{array}$ & $\begin{array}{c}\text { F- } \\
\text { change }\end{array}$ & Indep. & Dep. & $\begin{array}{c}\mathrm{R} \\
\text { square }\end{array}$ & $\begin{array}{c}\text { F- } \\
\text { change }\end{array}$ \\
\hline $\begin{array}{l}\text { EN } \\
<45\end{array}$ & CS4 & .398 & 3.970 & $\begin{array}{l}\text { EN } \\
<45\end{array}$ & CS7 & .496 & 3.542 & $\begin{array}{c}\text { EN } \\
<45\end{array}$ & 0 & .414 & 3.358 \\
\hline $\begin{array}{c}\mathrm{EC} \\
<45\end{array}$ & CS1 & .463 & 6.172 & $\begin{array}{c}\mathrm{EC} \\
<45\end{array}$ & CS3 & .330 & 5.216 & $\begin{array}{c}\mathrm{EC} \\
<45\end{array}$ & CS6 & .387 & 5.532 \\
\hline $\begin{array}{c}\mathrm{JS} \\
<45\end{array}$ & CS2 & .213 & 4.339 & $\begin{array}{c}\mathrm{JS} \\
<45 \\
\end{array}$ & CS1 & .324 & 4.276 & $\begin{array}{c}\mathrm{JS} \\
<45\end{array}$ & $\mathrm{CS} 1$ & .213 & 4.768 \\
\hline $\begin{array}{c}\text { EN } \\
45<\end{array}$ & CS7 & .189 & 4.117 & $\begin{array}{l}\text { EN } \\
<45 \\
\end{array}$ & CS7 & .247 & 4.275 & $\begin{array}{c}\text { EN } \\
<45 \\
\end{array}$ & CS7 & .142 & 4.298 \\
\hline $\begin{array}{c}\text { EC } \\
45<\end{array}$ & CS1 & .193 & 4.179 & EC & CS1 & .215 & 4.389 & $\mathrm{EC}$ & $\mathrm{CS} 1$ & .256 & 4.432 \\
\hline $\begin{array}{c}\text { JS } \\
45<\end{array}$ & CS1 & .172 & 4.052 & $\begin{array}{c}\text { JS } \\
<45 \\
\end{array}$ & CS1 & .195 & 4.367 & $\begin{array}{c}\text { JS } \\
<45\end{array}$ & CS1 & .184 & 4.438 \\
\hline
\end{tabular}

\section{DISCUSSION}

The reliability values of the alpha coefficient for measuring the construct are within the limits of acceptability, i. e. they belong to the rank of "average" and the rank of "good". Nunally and Bernstein (1994) state that in a preliminary study such like this, relatively lower values of the coefficient are tolerated, so that the range of values between 0.475 and 0.709 represents an acceptable level of interval consistency. The values of the Cronbach's alpha coefficients for the measurement constructs in this study are for the enterprise from 0.709 to 0.756 , the employee commitment from 0.475 to 0.589 , and the job satisfaction from 0.536 to 0.624 .

The results of Table 2 for US sample 2 entrepreneur correlation coefficient are for EN 1.00, for EC .453 and for JS .132. For US sample 2 Employee Commitment the correlation coefficient is for EN .472, for EC 1.100 and for JS .201. For US sample 2 Job Satisfaction the correlation coefficient is for EN .119, for EC .212 and for JS 1.980. From table 2 for Serbia and Bosnia and Herzegovina, the results are somewhat different. The results of the research show that there is a connection between entrepreneurship and employee commitment, as well as a positive attitude of entrepreneurs and job satisfaction.

$\mathrm{R}^{2}$ shows variance in employee commitment due to entrepreneurship and that is $\left(R^{2}=0.252\right)$, which is significant. Value of $\mathrm{F}$ is 70.134 , which is significant and level of significance is $(\mathrm{p}<0.01)$, which is totally acceptable and which tells that independent variable create variance in dependent variable. Value of standardized Beta of entrepreneurship is 8.375, which is significant having value i.e. $(p<0.01)$ and shows a significant impact of entrepreneurship on employee commitment.

$\mathrm{R}^{2}$ shows variance in job satisfaction due to authentic entrepreneurship and that is .017, which is significant. Value of $F$ is 4.632 , which is significant and level of significance having value i.e. $(\mathrm{p}<.01)$, which is totally acceptable and which tells that independent variable create variance in dependent variable.

Value of standardized Beta of Entrepreneurs is $(\beta$ $=0.131)$, which is significant. This shows a significant impact of entrepreneurship on employee commitment. Hierarchical regression analysis was used to examine the moderator effect of age of the respondents. Hierarchical regression analysis examined the significance of the regression coefficient with the product of the predictor variable for the independent variables EL and the dependent variables EC and JS and the moderator of age of the respondents.

The results of the hierarchical regression analysis ( $\mathrm{R}$ square and F-change) are presented in Table 6, and only the results in which the moderating effect of age of the respondents was confirmed. 


\section{CONCLUSION}

Global business conditions require a new organization to be innovative and creative, to improve business productivity and knowledge of all employees, especially entrepreneur-leaders. Entrepreneurial ideas for opening a new company as a conceptual entrepreneurial behavior and number of psychological and economic factors that influence entrepreneurial behavior, opened the door to new directions of scientific research. Moris et al. (2021) propose in their unique book for the emerging business arena of entrepreneurship and innovation seven perspectives in researching the nature of entrepreneurship:

- Entrepreneurship involves creating products and services in exchange for profit;

- Entrepreneurship includes realization of new companies/economic entities;

- Entrepreneurship involves activation of unique combination of resources that ultimately causes obsolescence of existing methods or products;

- Entrepreneurship involves making changes adjusting an individual's personal attitude and skills in order to respond to environmental circumstances;

- Entrepreneurship implies employment, management and development of factors of production, including human labor;

- Entrepreneurship is a process of creating value for customers by ranking on untapped opportunities;

- Entrepreneurship is defined as a strong positive orientation towards growth through an increase in sales, income and assets.

According to the result of this research, we concluded that there is a positive relationship among entrepreneurship and employee commitment and job satisfaction. Therefore, it can be said that entrepreneurship is a casual factor that influences employees' behavior.

\section{REFERENCES}

Akehurst, G., Akehurst, G., Comeche, J. M., \& Galindo, M. A. (2009). Job satisfaction and commitment in the entrepreneurial SME. Small Business Economics, 32(3), 277-289. https://doi.org/10.1007/s11187/0089116-Z

Argyris, C. (1993). Actionable Knowledge: Changing the Status Quo. San Francisco: Jossey-Bass.

Avolio, B. J., Zhu, W., Koh, W., \& Bhatia, P. (2004). Transformational leadership and organizational commitment: Mediating role of psychological empowerment and moderating role of structural distance. Journal of Organizational Behavior: The International Journal of Industrial, Occupational and Organizational Psychology and Behavior, 25(8), 951-968. https://doi.org/10.1002/job.283

Balofour, D., \& Barton, W. (1996). Organizational commitment: Antecedents and Outcomes in public Organizations. Public Productivity \& Management Review, 19(3), 256-277. https://doi.org/10.2307/3380574

Bernoster, I., Mukerjee, J., \& Thurik, R. (2020). The role of affect in entrepreneurial orientation. Small Business Economics, 54(1), 235-256. https://doi.org/10.1007/s11187-018-0116-3

Chandler, G.N., \& Hanks, S. H. (1994). Founder competence, the environment and venture performance. Entrepreneurship: Theory and Practice, 18(3), 77-90. https://doi.org/10.1177/104225879401800306

Ćoćkalo, D., Đorđević, D., Nikolić, M., Stanisavljev, S., $\&$ Terek, E. (2017). Analysis of possibilities for improving entrepreneurial behaviour of young people: Research results in Central Banat district. Journal of Engineering Management and Competitiveness (JEMC), 7(2), 97-108.

Đorđević, D., i Ćoćkalo, D. (2017). Preduzetništvo $i$ mladi u Srbiji: Perspektiva stanja i predlog smernica za unapređenje. Univerzitet u Novom Sadu Tehnički fakultet "Mihajlo Pupin", Zrenjanin, 19- 50, 2019.

Gatner, B. W. (1990). What are we talking about when we talk about entrepreneurship?, Journal of Business Venturing, 5(1), 15-28. https://doi.org/10.1016/0883-9026(90)90023-M

Gimeno, J., Folta, T.B., Cooper, A.C., \& Woo, C.Y. (1997). Survival of the fittest? Entrepreneurial human capital and the persistence of underperforming firms. Administrative Science Quarterly, 42, 750-783. https://doi.org/10.2307/2393656

Greenberg, J., \& Baron, R. A. (1995). Behavior in Organizations, Understanding and Managing the Hunan Side of Work. Prentice-Hall Inc.

Harter, J. K., Schmidt, F. L., \& Killham, E. A. (2003). Employee engagement, satisfaction, and businessunit-level outcomes: A meta-analysis. Princeton, NJ: Gallup Organization.

Hamel, G. (2000). Leading the Revolution. Harvard Business School Press, Boston, Massachusetts.

Henderson, J. E., \& Hoy, W. K. (1983). Leader authenticity: The development and test of an operational measure. Educational and Psychological Research, 3(2), 63-75.

Herzberg, F. (1987). One more time: how do you motivate employees?, Harvard Business Review, 65(5), 109-20.

Hiam, A. (2002a). The secret to entrepreneurial success.

https://www.entrepreneur.com/article/0,4621,30472 6,00 . 
Hiam, A. (2002b). Motivational Management, Inspiring Your People for Maximum Performance. Amacom, American Management Association, New York.

Hitt, M. A., \& Duane, R. (2002). The essence of strategic leadership: Managing human and social capital. Journal of Leadership \& Organizational Studies, 9(1), 3-14. https://doi.org/10.1177/107179190200900101

Iyigun, M.F., \& Owen, A.L. (1999). Entrepreneurs, Professionals, and Growth. Journal of Economic Growth 4, 213-232. https://doi.org/10.1023/A:1009806622022

Jensen, S. M., \& Luthans, F. (2006). Relationship between entrepreneurs' psychological capital and their authentic leadership. Journal of Managerial Issues, 18(2), 254-273. https://www.jstor.org/stable/40604537

Kanter, R. M. (1968). Commitment and social organization: A study of commitment mechanisms in utopian communities. American Sociological Review, 33(4), 499-517. https://doi.org/10.2307/2092438

Kreiner, H. J. (2011). Tools for success in contemporary industrial world. I International Symposium Engineering Management and Competitiveness, (EMC 2011), University of Novi Sad, Technical faculty Mihajlo Pupin, Zrenjanin, 24-25th June, 3136.

Kritikos, A. S., (2015). Entrepreneurship and Economic Growth. International Encyclopedia of the Social \& Behavioral Sciences, 7, 675-680. https://doi.org/10.1016/B978-0-08-097086-8.940042

Li, J., Yang, F., Qi, J., Sun, R., \& Geng, R. (2021). The influence of job satisfaction on entrepreneurial intention: A cross-level investigation. International Small Business Journal, 02662426211018831. https://doi.org/10.1177/02662426211018831

Likert, R. (1932).Technique for the Measurement of Attitudes. Archives of Psychology, 22(140), 1-55.

Locke, E.A. (1976). Thenature and Causes of Satisfaction. Handbookof Industrial and Organizational Psichology, 1(2), 1297-1343.

Low, M. B., \& MacMillan, I. C. (1988). Entrepreneurship: Past research and future challenges. Journal of Management, 14(2), 139-161. https://doi.org/10.1177/014920638801400202

Dajani, D., \& Zaki, M. A. (2015). The impact of employee engagement on job performance and organizational commitment in the Egyptian banking sector. Journal of Business and Management Sciences, 3(5), 138-147. https://doi.org/10.12691/jbms-3-5-1.
Martin, J. K., \& Miller, G. A. (1986). Job Satisfaction and Absenteeism: Organizational, Individual and Job-related Correlates. Work and Occupations, 13(1), 33-46. https://doi.org/10.1177/0730888486013001003

McCleland, D. (1961). The Achieving Society. Princeton, NJ: Van Nostrand.

Moris, H. M., Kuratko, D., \& Covin, G. J. (2021).Corporate Entrepreneurship \& Innovation. Amazon book clubs. ISBN-10:0538478926

O’Reilly, C.A., \& Pfeffer, J. (2000). Hidden Value: How Great Companies Achieve Extraordinary Results with Ordinary People. Boston: Harvard Business School Press.

Nunnally, J. C., \& Bernstein, I. H. (1994). The Assessment of Reliability. Psychometric Theory, 3, 248- 292.

Peretto, P. F. (1999). Industrial development, technological change, and long-run growth. Journal of Development Economics 59(2), 389-417. https://doi.org/10.1016/S0304-3878(99)00018-8

Pfeffer J. (1998). The Human Equation: Building profits by putting people first. Boston, Harvard Business School Press.

Puglisi, M., Fasone, V., Pedrini, G., Gervasi, D., \& Faldetta, G. (2021). Using a dual system of reasoning in small businesses: Entrepreneurial decisions and subjective risk intelligence. International Entrepreneurship and Management Journal, 1-25. https://doi.org/10.1007/s11365-02100762-6

Robbins, S.P. (2002). Organizational behaviors. (9th ed.). Upper Saddle River, NJ: Prentice Hall.

Sajfert, D., Kreiner, J., Škrinjarić, Z., \& Jančev, N. (2017a). Behavior of big Five Personality Factors on General Job Satisfaction. VII International Symposium Engineering Management and Competitiveness, (EMC 2017), 16-17th June, 150154.

Sajfert, D., Nikolić, M., Vukonjanski, J., Terek, E. \& Vulović, M. (2017b). The impact of leader's behavior on certain individual and organizational effects: The Serbian case. Journal of East European Management Studies, 22(4), 444-483.

Scheier, M. F., Weintraub, J. K., \& Carver, C. S. (1986). Coping with stress: Divergent strategies of optimists and pessimists. Journal of Personality and Social Psychology, 51(6), 1257-1264. https://doi.org/10.1037/0022-3514.51.6.1257

Spector, P. E. (1997). Job satisfaction: Application, assessment, causes, and consequences. Thousand Oaks, CA: Sage. 


\section{UTICAJ PREDUZETNIKA NA ZADOVOLJSTVO POSLOM I ORGANIZACIONU POSVEĆENOST ZAPOSLENIH: KOMPARATIVNA STUDIJA MALIH PREDUZEĆA}

U radu koristimo analize pouzdanosti, korelacije, regresiju obaveza zaposlenih, poredimo regresiju zaposlenih, regresiju zadovoljstva poslom i hijerarhijsku regresionu analizu. Kao tehnike za upoređivanje preduzetnika i zadovoljstva zaposlenih poslom i organizacionom posvećenošću koristili smo 36 nezavisnih uzoraka i 210 pojedinaca. Nalazi otkrivaju da: (1) Rezultati istraživanja su potvrdili postojanje statistički značajne pozitivne korelacije između determinanti zadovoljstva poslom i organizacione posvećenosti $s$ jedne strane i posla preduzetnika, sa druge strane; (2) Rezultati istraživanja upoređuju odnos između preduzetnika i zadovoljstva poslom zaposlenih i organizacione posvećenosti, dodajući značajno povećanje važnosti konstruktu; (3) Preduzetništvo ima relativnu korelaciju u odnosu na zadovoljstvo poslom i organizacionu privrženost i time povećava obim obavljanja zadataka i efikasnost preduzetnika. (4) Preduzetnici pokazuju dominaciju nad zadovoljstvom zaposlenih i organizacionom posvećenosti, kada predviđaju uspeh grupe ili organizacije i organizaciono građansko ponašanje. Preporučujemo da se u budućim istraživanjima ispitaju odnosi među preduzetnicima i njihovi odnosi sa zaposlenima, kao i zadovoljstvo poslom i organizacionom posvećenošću, kako bi se potencijalno uporedili.

Ključne reči: Preduzetništvo; Zadovoljstvo poslom; Organizaciona posvećenost; Efikasnost preduzetnika. 